\title{
Management Strategies of Service Providers and Post-Travel Opinion of Bus Passengers' (With Reference to Government and Private Omni Bus Operating Enterprises and its Services from Chennai)
}

\section{A. Gajendran}

\begin{abstract}
The present research study primarily focuses on the post-travel Opinion of the bus passengers' who availed the service provider of SETC, TNSTC, and Private Omnibuses. An effort was made to detect, ascertain and to know commuters by bus opinions after their travel which is the primary reason for their level of satisfaction. A short analysis report is made on services, service delivery systems, how far the passengers satisfied with the facilities and frequency of service towards the service provider. In addition, the present study connects with behavior, brand loyalty towards the service provider. The reviews were properly taken into consideration for finding the gap between earlier and present study. The adequate statistical tools such as t-test, chi-square test, ANOVA, multi-regression analysis were used to test hypotheses related to the current topic. The variables connect with post-travel experience, the grouping of variables, factor analysis, adequate statistical tools was used. Objective-based findings, suggestions, and conclusions are given at an appropriate level to carry out further research.
\end{abstract}

Keywords: Post Travel Experience, Passengers' Satisfaction, Service Provider, Metropolitan Transport Corporation.

\section{INTRODUCTION}

Peripatetic of people from one place to another is possible because of transport. Transport brings a lot of changes in human life. Initially bull karts used for transporting goods then because of technological development a lot of technological advancement that existed with transporting goods. Due to technical advancement, the steam engines were used, Boeing flights used for public transport. It is a known fact that everyone knows that roadways, railways, and airways mostly used for public transportation. Out of all modes of transportation modes, bus transport is the appropriate mode of transportation which is used for transporting people to various destinations. Buses operated by government side theaters a vigorous part in the arena of service industry and in every day's life of commuters.

An attempt was made in the current research paper to understand and to justify the identified assumptions to prove the facts. The data from prime source were composed by distributing opinion poll surveys tools to the commuters of Chennai Metropolitan Bus Terminal. The opinion poll framed in both English and vernacular language to make travellers to understand the concept and purpose of data collection and to provide appropriate answers. The secondary data were collected on the basis of necessity from various sources like newspapers, government official websites, and magazines and from the existing records. The researcher collected by using simple random sampling and convenience sampling methods.

The present study focuses on the differences between the services offered by both government and free bus enterprises with reference to Chennai. The data collected in four different segments which connect with attitude, psychology, PTE (Pre-travel Experience) and PTO of the passenger's. Out of all these segments, three of the segments related researches were published in international journals and the last segment of the data collection yet to be published and the researcher intended to publish it now. That is the main reason for the outcome of the present research. The researcher identified twelve variables which are connecting with passengers' post-travel opinions. Grouping of variables, factor analysis, cluster analysis, pilot study, association check, the combined impact of self-governing variables on dependent factors, relationship between independent variables and dependent factors, the most influencing factors which influence passenger's level of satisfaction were checked with appropriate tools. The results and discussions, finding, suggestions, and conclusions with regard to the present research were provided for better understating of the readers.

\section{STATEMENT OF PROBLEM}

Many research papers published earlier connects with passenger satisfaction focus on the satisfaction level of commuters traveling in bus. But the researchers might not give that many considerations for passenger's opinions after their travel through that particular mode of transportation. So it's mandatory to consider the opinion of the bus passengers after their travel. Therefore the attempt made to identify, 
analyze the opinion of the bus passengers to upgrade the quality standards of the service provider. This paper concentrates and tries to identify what kind of opinion, the view is expressed by the passengers who are traveling in bus specifically by SETC, TNSTC, and Private Omnibuses.

\section{OBJECTIVES OF THE STUDY}

- To observe the factors connects with the post-travel opinion which influences passenger's satisfaction level.

- To highlight the post-travel experience and opinion of the passengers towards their travel and transport services offered by their service providers.

\section{HYPOTHESIS}

No significant variance in PTO among government and free bus enterprises at Chennai.

\section{RESEARCH METHODOLOGY}

The observed data used in this study collected from prime and bases from ancillary sources. The prime statistics are composed by the mixtures of research opinion poll from commuters who will commence their travel from Koyambedu bus terminus and nearby boarding points. The questionnaire contains both dependent and independent variables. Likert ruler is availed to quantify the fulfillment of travellers based on their PTO. The researcher hopes that this research paper is the first attempt in the Chennai District in this field. Passengers were asked questions about their experience and after travel opinion by the researcher and by his trained investigators. The simple random sampling and convenience sampling method were used for this research paper.

\section{DATA COLLECTION, SURVEY AND SAMPLE SIZE}

The passengers' Survey conducted by the researcher through this research to monitor post-travel experience and passengers opinion towards the government bus transport service industry (Excepting MTC) which includes only distantly operated buses such as SETC, TNSTC and private buses operated from various Chennai destinations within the 200 to 300 kilo meter radius. This research is an element of researchers' overall research work on passenger satisfaction. Due to some restrictions, the researcher of this research paper not able to disclose his research work for a couple of years. $\mathrm{He}$ felt this is the appropriate time for him to release his research findings for the benefit of the society and for upgrading the quality standards of the bus transport service sector. By grouping of variables, the factors are identified and factor and cluster analysis were used to identify the most inducing influences of commuters' opinion after their travel.

Respondents chosen for this study includes Chennai district commuters only. Five hundred samples were collected from service providers by various transport industries operated in Chennai city. Out of the total collected samples, one hundred and nine samples, two hundred and sixteen samples from SETC, TNSTC. The rest of the 175 samples collected from private sector Omnibus passengers.

\section{LIMITATIONS OF THE STUDY}

- The present study includes only the bused operated in long distance.

- The research study eliminates MTC and her buses operated lesser than 50 Kilo meters from Chennai district.

- The researcher collected information from respondents able to understand the questions in the research questionnaire.

\section{RESULTS AND DISCUSSIONS}

The pilot study carried out with forty samples and after that based on the suggestions given by samples were taken into consideration and the same was incorporated with the earlier questionnaire. The reliability test was also done. The dependent and independent variables are determined. Finally, with the help SPSS Version 20, the collected data were scrutinized, tabulated and the following results were found and the same was provided for readers' understanding. Primarily the demographical factors of the passengers are given as follows:

Schedule - 1

Frequency Distribution - Demographical Variables

\begin{tabular}{|c|c|c|c|}
\hline Age & $\%$ & Gender & $\%$ \\
\hline $\begin{array}{l}<20 \\
\mathbf{2 1 - 4 0} \\
41-60 \\
>60 \\
\text { Total }\end{array}$ & $\begin{array}{l}24.4 \\
\mathbf{6 1 . 4} * \\
12.6 \\
1.6 \\
100.0\end{array}$ & $\begin{array}{l}\text { Male } \\
\text { Female } \\
\text { Total }\end{array}$ & $\begin{array}{l}49.0 \\
\mathbf{5 1 . 0} * \\
100.0\end{array}$ \\
\hline Marital Status & $\%$ & $\begin{array}{l}\text { Passengers' } \\
\text { Segmentation }\end{array}$ & $\%$ \\
\hline $\begin{array}{l}\text { Married } \\
\text { Single } \\
\text { Others } \\
\text { Total }\end{array}$ & $\begin{array}{l}\mathbf{5 5 . 2} * \\
43.4 \\
1.4 \\
100.0\end{array}$ & $\begin{array}{l}\text { Student } \\
\text { Trade Individuals } \\
\text { Remunerated } \\
\text { People } \\
\text { Retired Individual } \\
\text { Freelancers } \\
\text { Others } \\
\text { Total }\end{array}$ & $\begin{array}{l}29.6 \\
4.8 \\
\mathbf{5 3 . 4 *} \\
1.4 \\
3.8 \\
7.0 \\
100.0\end{array}$ \\
\hline $\begin{array}{l}\text { Income } \\
\text { segmentation }\end{array}$ & $\%$ & & \\
\hline $\begin{array}{l}<100 \text { thousands } \\
< \\
\text { thousands } \\
<300 \text { thousand } \\
300 \&>=300 \\
\text { thousands } \\
\text { Total }\end{array}$ & $\begin{array}{l}26.4 \\
\mathbf{3 6 . 4} * \\
19.2 \\
18.0 \\
100.0\end{array}$ & & \\
\hline
\end{tabular}

\section{Source: Primary Data}

In addition to demographical factors, the use of an self-governing t-test carried the succeeding outcomes and the same given as follows in table - 2 : 
Schedule - 2 : Cluster Statistics - PTO of the Bus Commuters

\begin{tabular}{|c|c|c|c|c|c|c|c|}
\hline $\begin{array}{c}\text { Variable } \\
\text { No. }\end{array}$ & Service Provider & $\begin{array}{c}\text { Total } \\
\text { Frequency }\end{array}$ & Average & $\begin{array}{l}\text { Standard } \\
\text { Deviation }\end{array}$ & $\begin{array}{c}\text { Standard } \\
\text { Error } \\
\text { Mean }\end{array}$ & $\mathbf{t}$ & $\begin{array}{c}\text { Probabilit } \\
\text { y value }\end{array}$ \\
\hline \multirow{2}{*}{ PTO1 } & GB & TFGB1 & 2.73 & .991 & .055 & -0.21 & 0.84 \\
\hline & OB & TFOB2 & 2.75 & 1.031 & .078 & & \\
\hline \multirow{2}{*}{ PTO2 } & GB & TFGB1 & 2.76 & .941 & .052 & -0.16 & 0.88 \\
\hline & OB & TFOB2 & 2.78 & .978 & .074 & & \\
\hline \multirow{2}{*}{ PTO3 } & GB & TFGB1 & 2.84 & .988 & .055 & 0.03 & 0.98 \\
\hline & OB & TFOB2 & 2.83 & 1.023 & .077 & & \\
\hline \multirow{2}{*}{ PTO4 } & GB & TFGB1 & 2.79 & .940 & .052 & 0.06 & 0.95 \\
\hline & OB & TFOB2 & 2.79 & .93 & .07 & & \\
\hline \multirow{2}{*}{ PTO5 } & GB & TFGB1 & 2.92 & .944 & .052 & 0.10 & 0.93 \\
\hline & $\mathrm{OB}$ & TFOB2 & 2.91 & .967 & .073 & & \\
\hline \multirow{2}{*}{ PTO6 } & GB & TFGB1 & 2.98 & .984 & .055 & -0.32 & 0.75 \\
\hline & OB & TFOB2 & 3.01 & 1.042 & .079 & & \\
\hline \multirow{2}{*}{ PTO7 } & GB & TFGB1 & 2.97 & 1.067 & .059 & -0.16 & 0.87 \\
\hline & $\overline{\mathrm{OB}}$ & TFOB2 & 3.00 & 1.077 & .081 & & \\
\hline \multirow{2}{*}{ PTO8 } & GB & TFGB1 & 3.2 & 1.055 & .059 & -0.2 & 0.84 \\
\hline & $\mathrm{OB}$ & TFOB2 & 3.22 & 1.078 & .082 & & \\
\hline \multirow{2}{*}{ PTO9 } & GB & TFGB1 & 3.36 & 1.0667 & .059 & -0.3 & 0.80 \\
\hline & OB & TFOB2 & 3.38 & 1.1125 & .084 & & \\
\hline \multirow{2}{*}{ PTO10 } & GB & TFGB1 & 3.23 & 1.111 & .062 & 0.3 & 0.77 \\
\hline & OB & TFOB2 & 3.20 & 1.14 & .086 & & \\
\hline \multirow{2}{*}{ PTO11 } & GB & TFGB1 & 3.23 & 1.097 & .061 & 0.4 & 0.72 \\
\hline & $\mathrm{OB}$ & TFOB2 & 3.19 & 1.092 & .083 & & \\
\hline \multirow{2}{*}{ PTO12 } & GB & TFGB1 & 3.05 & 1.3 & .072 & 0.24 & 0.81 \\
\hline & OB & TFOB2 & 3.02 & 1.36 & .103 & & \\
\hline
\end{tabular}

Source: Computed Data / TFGB: Total frequency of Government Buses 325 samples / TFOB: Total frequency of Omni Buses 175 Samples

PTO: Post Travel Opinion; GB: Government Buses; OB: Omni Private Bus

The above table shows the calculated probability results for the various DV(dependent variables) of PTO given, that are: Trustworthiness $(\mathrm{p}=0.84)$,Suitability $(\mathrm{p}=0.88)$, Driving capability of driver $(\mathrm{p}=0.98)$, Responses level of conductors $(\mathrm{p}=0.95)$, time usage and speed $(\mathrm{p}=0.93)$, safety at bus travel $(\mathrm{p}=0.75)$, Comfort in receipt of quality service $(\mathrm{P}=$ $0.87)$, cheap cost $(\mathrm{p}=0.84)$, inside bus temperature and Humidity ( $\mathrm{p}=0.80)$, Bus Quality status $(\mathrm{p}=0.77)$, free from noise disturbances $(p=0.72)$, installation of accessories such as Medical Kit, TV sets, DVD players, Sitting cushion chairs, installation of Glows in bus, ventilators or air coolers, Safety seat straps, providing air cushions $(\mathrm{p}=0.81)$ and so on.

From the statistical computation and calculated $p$ values, it is resolved that there is no variance between the PTO of the commuters of both government buses and private bus travellers. It proves that both categories of commuters having the similar opinion about their travel towards the influences named as Trustworthiness, Comfort level and Service related Enactments.

\section{Factor Analysis}

The post-travel opinion is connected with what kind of experience the passengers felt after their travel in bus. With reference to the bus passengers post-travel experience, they will finalize or decide on their upcoming travel bookings with similar service facilitators or to prefer a fresh one or shift over from one service facilitator to alternative facilitator. In commuters interpretations, all the destructive and optimistic aspects of service providers are identified, collected, gathered information and consolidated those aspects by the researcher for his research study. The factors connected with post-travel opinion totally include 12 variables.

Analyses were done in a proper manner, outcomes are originated in appropriate ways and that are given in the following paragraph. In association with this, the factor analysis executed with said variables on service facilitators, enabling commuters upcoming decisions on travel-related policies. The outcomes of factor investigation were observed, provided in the succeeding schedule. 
Management Strategies of Service Providers and Post-Travel Opinion of Bus Passengers' (With Reference to Government and Private Omni Bus Operating Enterprises and its Services from Chennai)

\begin{tabular}{|l|l|l|}
\hline \multicolumn{2}{|l|}{ KMO Sampling Adequacy. } & 0.91 \\
\hline Test of Sphericity & $\begin{array}{l}\text { Chi Square } \\
\text { Value }\end{array}$ & 49.0 \\
\hline & $\begin{array}{l}\text { V= Degree of } \\
\text { freedom }\end{array}$ & 66.0 \\
\hline & Significance & 00.0 \\
\hline
\end{tabular}

Schedule - 3 : KMO \& Bartlett's Test for PTO of Travellers
Source: Primary data

It is originated form the table that the KMO sampling adequacy value is 0.91 , Chi-square value 49 is significant. Therefore it is confirmed that there is a possibility of reduction of data with PTO variables of commuters.

Schedule - 4 : Crosstab between PTO of the Passengers' and their Age

\begin{tabular}{|c|c|c|c|c|c|}
\hline \multirow{2}{*}{ Passengers' Opinion } & \multicolumn{4}{|c|}{ Age (In years) } & \multirow{2}{*}{$\begin{array}{l}\text { Total } \\
1.00\end{array}$} \\
\hline & Below 21 & $>21$ and $<40$ & $>=41$ to $<60$ & $>=60$ & \\
\hline $\begin{array}{l}\text { MS* } \\
\text { HS* } \\
\text { DS* } \\
\text { Total }\end{array}$ & $\begin{array}{l}68(26.6 \%) \\
16(16.7 \%) \\
38(25.7 \%) \\
122(24.4 \%)\end{array}$ & $\begin{array}{l}15(59.80 \%) \\
64(66.70 \%) \\
90(60.80 \%) \\
307(61.40 \%)\end{array}$ & $\begin{array}{l}35(13.7 \%) \\
8(8.3 \%) \\
20(13.5 \%) \\
63(12.6 \%)\end{array}$ & $\begin{array}{l}0(0.0 \%) \\
8(8.3 \%) \\
0(.0 \%) \\
8(1.6 \%)\end{array}$ & $\begin{array}{l}256 \\
96 \\
148 \\
500\end{array}$ \\
\hline \multirow{2}{*}{\multicolumn{3}{|c|}{$\begin{array}{l}\text { Chi-Square Value } \\
38.90\end{array}$}} & $\begin{array}{l}\text { Degree of } \\
\text { freedom }\end{array}$ & \multicolumn{2}{|l|}{ Sig. } \\
\hline & & & 6 & \multicolumn{2}{|l|}{0.000} \\
\hline
\end{tabular}

Source: Primary data

*MS: Moderately Satisfied; *HS: Highly Satisfied; *DS: Dissatisfied

It is originated that $59.80 \%$ of MS respondents or commuters age is between the age group of $>=21$ and $<=40$, $66.70 \%$ of HS customers are identified between the age group of $>=21$ and $<=40$ years. In addition, It was observed that $60.80 \%$ of DS travellers also found in between the age group of $>=21$ and $<=40$. In addition, Pearson's chi-square output is 38.90 and probability value $=0.000$. it confirms that there is a significance at $5 \%$. It is determined that there was an affiliation between the PTO of commuters and the age of commuters among two dissimilar service facilitators.

Association check among PTO of commuters and various divisions of commuters:

In the below mentioned schedule, the commuters are divided in to various categories namely, pupil, business individuals, remunerated individuals, discharged, freelancers. With the three numbers of clusters, sub divided groupings among commuters are provided in orderly manner. The detected frequencies provided in the following schedule: 
Schedule 5 : Crosstab among PTO and Various Commuters Groupings

\begin{tabular}{|c|c|c|c|c|c|c|c|c|}
\hline \multicolumn{2}{|c|}{ Clusters and its categories } & \multicolumn{6}{|c|}{ Division on Commuters } & \multirow{2}{*}{ Total } \\
\hline & & $\mathrm{S}$ & BP & SP & $\mathrm{R}$ & SE & Others & \\
\hline $\begin{array}{l}\text { MS } \\
\text { HS } \\
\text { DS } \\
\\
\text { Total }\end{array}$ & $\begin{array}{l}\text { Count } \\
\text { in } \\
\%\end{array}$ & $\begin{array}{l}57 \\
22.3 \% \\
32 \\
33.3 \% \\
59 \\
39.9 \% \\
148 \\
29.6 \%\end{array}$ & $\begin{array}{l}19 \\
7.4 \% \\
5 \\
5.2 \% \\
0 \\
.0 \% \\
24 \\
4.8 \%\end{array}$ & $\begin{array}{l}150 \\
58.6 \% \\
41 \\
42.7 \% \\
76 \\
51.4 \% \\
267 \\
53.4 \%\end{array}$ & $\begin{array}{l}7 \\
2.7 \% \\
0 \\
.0 \% \\
0 \\
.0 \% \\
7 \\
1.4 \%\end{array}$ & $\begin{array}{l}2 \\
.8 \% \\
10 \\
10.4 \% \\
7 \\
4.7 \% \\
19 \\
3.8 \%\end{array}$ & $\begin{array}{l}21 \\
8.2 \% \\
8 \\
8.3 \% \\
6 \\
4.1 \% \\
35 \\
7.0 \%\end{array}$ & $\begin{array}{l}256 \\
100 \% \\
96 \\
100 \% \\
148 \\
100 \% \\
500 \\
100 \%\end{array}$ \\
\hline \multirow{2}{*}{\multicolumn{2}{|c|}{ Chi-Square Value }} & & \multirow{2}{*}{\multicolumn{2}{|c|}{51.5}} & Df & \multicolumn{3}{|c|}{ Asymp. Sig. (2-sided) } \\
\hline & & & & & 10 & \multicolumn{3}{|l|}{.000} \\
\hline
\end{tabular}

Source: Primary data

S: Student/ BP: Business People/SP: Salaried Person/RP: Retired Person/SF: Self employed

It was concluded that out of various segmentations of the bus passengers and their opinion, $58.60 \%$ of MS commuters fit to salaried income category. In addition to it, it is observed that $42.70 \%$ of commuters of the HS cluster identified at pupil's category. It was found that $51.40 \%$ of DS travellers fit to the remunerated individual's category. It was also determined that the value of chi-square test is 51.50 and the probability value is 0.000 . It was concluded that there is significance among the above mentioned variables at $5 \%$. Therefore it was concluded that there is an association among PTO and the divisions of commuters to select service facilitators for their travelling.

Schedule - 6 : Crosstab among PTO of Commuters and SETC

\begin{tabular}{|c|c|c|c|c|}
\hline \multirow{2}{*}{\multicolumn{2}{|c|}{ Commuters' Opinion }} & \multicolumn{2}{|l|}{ SETC } & \multirow{2}{*}{ Total } \\
\hline & & $\begin{array}{l}\text { Positive } \\
\text { Response }\end{array}$ & $\begin{array}{l}\text { Negative } \\
\text { Response }\end{array}$ & \\
\hline $\begin{array}{l}\text { MS } \\
\text { HS } \\
\text { DS } \\
\text { Total }\end{array}$ & $\begin{array}{l}\text { Count in } \\
\text { Percentage }\end{array}$ & $\begin{array}{l}199(78 \%) \\
47(49 \%) \\
130(88 \%) \\
376(75 \%)\end{array}$ & $\begin{array}{l}57(22 \%) \\
49(51 \%) \\
18(12 \%) \\
124(25 \%)\end{array}$ & $\begin{array}{l}256 \\
96 \\
148 \\
500\end{array}$ \\
\hline \multirow{2}{*}{$\begin{array}{l}\text { Chi-Square Value } \\
69\end{array}$} & \multicolumn{2}{|c|}{ Degree of freedom } & \multicolumn{2}{|l|}{ Sig. } \\
\hline & \multicolumn{2}{|l|}{4} & \multicolumn{2}{|l|}{.000} \\
\hline
\end{tabular}

Source: Primary data

*MS: Moderately Satisfied / *HS: Highly Satisfied/*DS: Dissatisfied

The above table shows that in the primary cluster , $78.0 \%$ of commuters are replied and given positive reply and they indicated that they are moderately satisfied with the SETC service and its facilities. Then it was observed that as per the second cluster, $49.0 \%$ of bus travellers were HS with the facilities and services of SETC. Finally, the final cluster of commuters indicated that they are dissatisfied with SETC and its facilities and services. In addition, It was determined that Chi-square value 69 and probability value 0.000 proves that there is a an association among PTO and the commuters satisfaction on the road to the service facilitator SETC.

The below schedule providing details of commuters views and their satisfaction scale on service facilitator TNSTC. 
Management Strategies of Service Providers and Post-Travel Opinion of Bus Passengers' (With Reference to Government and Private Omni Bus Operating Enterprises and its Services from Chennai)

Schedule - 7 : Association among PTO of Commuters and TNSTC

\begin{tabular}{|c|c|c|c|c|}
\hline \multirow{2}{*}{\multicolumn{2}{|c|}{ Commuters Opinion }} & \multicolumn{2}{|c|}{ TNSTC } & \multirow{2}{*}{ Total } \\
\hline & & Pecitive Pesnonce & Negative & \\
\hline $\begin{array}{l}\text { MS } \\
\text { HS } \\
\text { DS } \\
\text { Total }\end{array}$ & Count in Percentage & $\begin{array}{r}182.0(71.10 \%) \\
38.0(39.60 \%) \\
102.0(68.90 \%) \\
322.0(64.40 \%)\end{array}$ & $\begin{array}{r}74.0(28.90 \%) \\
58.0(60.40 \%) \\
46.0(31.10 \%) \\
178.0(35.60 \%)\end{array}$ & $\begin{array}{r}256.0 \\
96.0 \\
148.0 \\
500.0\end{array}$ \\
\hline \multirow{2}{*}{\multicolumn{3}{|c|}{ Chi-Square Value $=32.1$}} & $\begin{array}{c}\text { Degree of } \\
\text { Freedom }\end{array}$ & Sig. Value \\
\hline & & & 2 & 0.000 \\
\hline
\end{tabular}

Source: Primary data / PTO: Post Travel Opinion of the Passengers'

With reference to the above details given in the above schedule, it was described that out of all selected commuters of the prime cluster, 71.10 percentages of commuters responded and given positive response like they are MS with the facilities of the service facilitator TNSTC. It was observed that out of total commuters of second cluster, 60.40 percentages of them are HS with the facilities and service provided by TNSTC. Adding to the above statement, 68.90 percentages of travellers of third cluster indicate that the commuters are satisfied with the existing services of TNSTC.

It is concluded that (calculated Chi-square value is 32.10 and probability value is 0.000) there is a variance in affiliation among PTO and Service facilitator TNSTC at 5 percent. As per the results of above schedule, it was determined that there is an rapport among PTO of commuters and their satisfaction level of service facilitator TNSTC.

In connection with the investigation of groups for identifying PTO of commuters of both transport sectors such as government and private respectively and variance analysis were also used in the given schedule to recognize whether there is an impact between autonomous variables on PTO of travellers.

Schedule: 8 : ANOVA for Influence of Age on PTO of Commuters of Government and Private Bus Enterprises of Chennai District

\begin{tabular}{|c|c|c|c|c|c|c|}
\hline Factors of PTO & & $\begin{array}{l}\text { Total of } \\
\text { Squares }\end{array}$ & $\begin{array}{l}\text { Degre } \\
\mathrm{e} \text { of } \\
\text { freedo } \\
\mathrm{m}\end{array}$ & $\begin{array}{l}\text { Average } \\
\text { Square }\end{array}$ & $\mathrm{F}$ & Sig. \\
\hline \multirow{3}{*}{ Comfort Level } & Between Clusters & 15.5 & 3 & 5.2 & \multirow{3}{*}{7.1} & \multirow{3}{*}{0.000} \\
\hline & Within Clusters & 363.2 & 496 & 0.7 & & \\
\hline & Total & 378.7 & 499 & & & \\
\hline \multirow{3}{*}{$\begin{array}{l}\text { Service } \\
\text { enactments }\end{array}$} & Between Clusters & 15.5 & 3 & 5.2 & \multirow{3}{*}{7.6} & \multirow{3}{*}{0.000} \\
\hline & Within Clusters & 335.4 & 496 & .68 & & \\
\hline & Total & 350.9 & 499 & & & \\
\hline \multirow{3}{*}{ Trustworthiness } & Between Clusters & 19.7 & 3 & 6.6 & \multirow{3}{*}{8.2} & \multirow{3}{*}{0.000} \\
\hline & Within Clusters & 398.3 & 496 & 0.8 & & \\
\hline & Total & 418.017 & 499 & & & \\
\hline
\end{tabular}

Source: Prim data / V = Degree of freedom / F = Frequency

The above schedule clears depicts that, it was concluded hints to the comparison of average variance at age clusters. This try to means that the commuters age cluster $>=60$ are highly gratified through PTO towards their comfort level $($ Average $=3.80)$, Service related enactment $($ Average $=4)$ and Trustworthiness (Average $=4.0$ ). the comfort level (F value is 7.10, Probability value is 0.0 ), Service related enactments $(\mathrm{F}$ value $=7.6$, Probability value $=0.0$ ), Trustworthiness ( $\mathrm{F}$ value is 8.174 , Probability value $=0.0$ ) are induced by the age group at 5 percentage. It 
Schedule - 10 : PTO - Inducing and Non- inducing Factors

\begin{tabular}{|c|c|c|c|c|}
\hline $\begin{array}{l}\text { Serial } \\
\text { Number }\end{array}$ & $\begin{array}{l}\text { Respondent } \\
\text { related variables }\end{array}$ & $\begin{array}{l}\text { Acceptance I } \\
\text { Non Acceptance } \\
\text { Association }\end{array}$ & Inducing Factors & Non-Inducing Factors \\
\hline 1 & Age & Accepted & $\begin{array}{l}\text { Comfort level } \\
\text { Trustworthiness } \\
\text { Service Performance }\end{array}$ & NA \\
\hline 2 & Gender & Not accepted & $\begin{array}{ll}\text { Service } & \text { related } \\
\text { Enactment } & \end{array}$ & $\begin{array}{l}\text { Comfort Level } \\
\text { Trustworthiness }\end{array}$ \\
\hline 3 & Wedded Status & Accepted & NA & $\begin{array}{l}\text { Comfort Level } \\
\text { Trustworthiness } \\
\text { Service related } \\
\text { enactments }\end{array}$ \\
\hline 4 & $\begin{array}{l}\text { Divisions } \\
\text { commuters }\end{array}$ & Not Accepted & $\begin{array}{l}\text { Comfort Level } \\
\text { Trustworthiness } \\
\begin{array}{l}\text { Service related } \\
\text { enactments }\end{array}\end{array}$ & NA \\
\hline 5 & $\begin{array}{l}\text { Earnings level of } \\
\text { respondents }\end{array}$ & Accepted & $\begin{array}{l}\text { Comfort Level } \\
\text { Trustworthiness }\end{array}$ & $\begin{array}{ll}\text { Service } & \text { related } \\
\text { enactments }\end{array}$ \\
\hline & \multicolumn{4}{|c|}{ Satisfaction Level of Passengers' } \\
\hline \multirow[b]{3}{*}{6} & SETC & Accepted & NA & $\begin{array}{l}\text { Comfort level } \\
\text { Trustworthiness } \\
\text { Service related } \\
\text { enactments }\end{array}$ \\
\hline & TNSTC & Accepted & $\begin{array}{l}\text { Comfort level } \\
\text { Trustworthiness }\end{array}$ & $\begin{array}{ll}\text { Service } & \text { related } \\
\text { enactment } & \end{array}$ \\
\hline & $\begin{array}{l}\text { Private Omni } \\
\text { Buses }\end{array}$ & Not Accepted & $\begin{array}{l}\text { Comfort Level } \\
\text { Trustworthiness } \\
\text { Service related } \\
\text { enactments }\end{array}$ & NA \\
\hline 7 & Usage Period & Not Accepted & $\begin{array}{ll}\text { Comfort Level } & \\
\text { Service } & \text { related } \\
\text { enactments } & \end{array}$ & Trustworthiness \\
\hline
\end{tabular}

\section{Source: Computed Data}

It was perceived from above schedule that the age and commuters sub divisions are closely connected with groups of PTO and its stimuli of commuters. Chi-square results and variances analysis exposed that the aforementioned variables are allied by clusters and also creating high impact on the highest number of influences. The perceived conclusion is that the Comfort level, trustworthiness, Service related enactments were generally stimulated via age, commuters subdivisions. Hence, it is resolved that, Comfort level, trustworthiness and Service related enactments were leading in their observation. It was also originated that age, commuters' classifications are significant and autonomous variables deciding the PTO of travellers headed for several service facilitators at Tamil Nadu in bus transport services arena.

\section{RESULTS AND FINDINGS}

It was perceived that there is a connection among PTO of bus commuters' and self-governing variables like age, gender , wedded rank, commuters sub divisions, revenue levels, usage pattern and satisfaction level towards service facilitators such as SETC, TNSTC and Privately owned long distance buses. Out of the discussions and result, the following findings were provided in the following paragraph.

$60 \%$ and $67 \%$ of MS (Moderately satisfied)and HS(Highly satisfied) commuters respectively were identified among the age clusters from 21 to 40 years. In addition, it is depicted that there is an association between age and PTO of commuters.

$53 \%$ of the male travellers $68 \%$ of female travellers were found MS and HS commuters are satisfied with the facilities of service facilitators namely SETC and TNSTC and privately owned operated buses. It was resolved that there is a strong connection among gender classifications and PTO of commuters.

$55 \%$ of MS commuters and $56.30 \%$ of HS commuters are wedded. Moreover, it was observed that there is an association among PTO of travellers and the marital status of the passengers of different service providers.

$59 \%$ of MS commuters fit to remunerated revenue cluster. $42.70 \%$ of HS commuters are fit in to the pupils' community. 


\section{Management Strategies of Service Providers and Post-Travel Opinion of Bus Passengers' (With Reference to Government and Private Omni Bus Operating Enterprises and its Services from Chennai)}

It is also clinched that there is an affiliation among PTO of bus commuters and various categories of commuters to choice a service facilitator for their travelling.

$39 \%$ of MS commuters fit with the income cluster of $<200$ thousand rupees, correspondingly with the second group of clusters, $31.30 \%$ of commuters fits with the category of $<100$ thousand rupees revenue clusters. It is also resolved that there was a affiliation among PTO of commuters and their revenue cluster.

$55.10 \%$ of $\mathrm{MS}$ and $54.20 \%$ of HS commuters are habitually custom with the buses and its services for their own purposes. Also it is depicted that $52.30 \%$ of $\mathrm{MS}$ commuters and $46.90 \%$ of HS travellers believed that they will avail bus and its services occasionally for their commercial commitments. It was represented that there is a liaison between the PTO of commuters and their usage habit headed for own and commercial drives.

$78 \%$ of MS travellers and $49.0 \%$ of HS commuters are gratified with the amenities of SETC. It is detected that $71 \%$ of MS bus travellers are fulfilled with the facilities of TNSTC. It is also originated that there is a rapport among PTO of bus travellers and the commuters satisfaction level headed for the service facilitators such as SETC and TNSTC.

It is concluded that self-governing variables namely age, commuter sub divisions are closely correlated with the influences of PTO of bus travellers. Use of Chi square test analysis and variances analysis results that the above indicated self-governing variables generate high impact on more numbers of influences connects with PTO. While the researcher compared the above indicated two self-governing variables with dependent elements of PTO(comfort level, trustworthiness and service related enactments are extremely influenced by age and various categories of commuters. Hence, it was determined that the travellers PTO, comfort level, trustworthiness and service related enactments are primary in their perception. It was also originated that the age, various categories of commuters which confirms the PTO of commuters headed towards the choice of bus service facilitators such as SETC, TNSTC and privately owned Omni buses.

With reference to multiple regression analysis, it was identified that PTO analysis on comfort level of both service facilitators entirely influenced by with the bus ticket buying behaviors of commuters. In privately owned operated Omni buses, PTO headed for comfort influenced by ticket buying attitude of commuters, contributions and effort of the people who are serving with service facilitator to attract bus travellers.

Finally it was identified that the performances of government buses influenced by revenue level, ticket buying behavior of the travellers. Furthermore, it was also found that the performance of service facilitators of privately operated Omni buses entirely influenced by gender, wedded status of bus travellers. It is also observed that PTO of commuters headed for trustworthiness position of SETC and TNSTC influenced by contributions of the employees serving at government sector bus transport service industries at Chennai. On the other hand, it is identified that the PTO of travellers headed for privately operated Omni buses influenced by gender and wedded position of the commuters who travelled from Chennai.

\section{SUGGESTIONS}

- The researcher suggested that it is important to stress further on maintaining service efficiency, safety, security and maintenance functions, cautious increase in ticket rate, managing operative phase and comfort phase, installation and maintenance of special accessories, user-friendliness with the software when passengers' wants to avail it by booking through online mode, suitability and timely response of service personnel's to enhance services and providing quality in facilities by service facilitators to induce commuters and to hold predominant bus travellers.

- It is also advisable to the service facilitators to maintain alike primacy to various commuters such as teenagers, pupils, administrators, commercial persons, experts, and so on to induce commuters for using offered amenities of service facilitators.

- It is mandatory to provide importance on quality in maintenance, bus fare, comfort, behavior, attitude, and attentiveness on passengers, effective training on improving enactments of service peoples of facilitators and to boost operative spell administration to improve commuters fulfillment at several altitudes.

- It is also advisable to the service facilitators for initiating important steps to improve quality of services of bus transport service industries to attract satisfaction level of commuters to confirm their development in upcoming years.

\section{CONCLUSION}

From the above analysis, results, and discussions, the researcher concluded that it is mandatory for both service facilitators to offer additional priority for the passengers' attitude, taste, and preferences. The bus transport sectors should identify their convictions, behavior by conducting the survey, awareness programs which express the facilities that are given or introduced by them at present or in the near future. The service providers should make passengers to know about the recent up-gradation in their service-related facilities and also about the service quality standards. If a bus transport service provider fails to identify perception, attitude, taste, priority, and preferences of the passengers then surely they will lose their customers (passengers') and they may fail to achieve their business related objectives too. Therefore the success of the bus transport business starts from identifying the real attitude that is nothing but identifying the fundamental or basic needs and expectations of the passengers'. So it is too important for bus transportation divisions to concentrate high on commuters' expectations and to give high priority for the attitude, perception of passengers to get success in the bus transport business.

\section{REFERENCES}

1. www.passengerfocus.org.uk

2. www.tnstc.in

3. www.statistics.gov.uk 